MATEUSZ SZUREK

\title{
Assessment of the capacity to create and understand wordbuilding structures by a child with minor intellectual disability
}

\begin{abstract}
Mateusz Szurek, Assessment of the capacity to create and understand wordbuilding structures by a child with minor intellectual disability. Interdisciplinary Contexts of Special Pedagogy, no. 26, Poznań 2019. Pp. 39-58. Adam Mickiewicz University Press. ISSN 2300-391X. e-ISSN 2658-283X. DOI: https:/ / doi.org/10.14746/ ikps.2019.26.02

The research conducted on language of children with intellectual disability (ID) shows that they exhibit language dysfunctions on every level of language. Up to now, literature did not include linguistic studies concerning issues of wordbuilding in the language consciousness of pre-school children with intellectual disability. The objective of the article is the assessment of the level of wordbuilding competences of a child at pre-school age with minor intellectual disability (MID) concerning the creation and comprehension of nominal derivates in the area of selected wordbuilding categories (case study). In addition, the author wishes to stress that the assessment of the level of wordbuilding competences should be a component on comprehensive logopaedic diagnosis.
\end{abstract}

KEY WORDS: intellectual disability, word formation, word formation competences

\section{Wordbuilding competence tests}

Im foreign-language literature, a popular experiment aimed at testing the level of acquisition of wordbuilding rules by children was the WUG study conducted by Jean Berko ${ }^{1}$ (the author tested

${ }^{1}$ J. Berko, The child's learning of English morphology, “Word” 1958, no. 14, pp. 150-177. 
capacities spanning the creation of nominal diminutives, names of actors in activities, nominal adjectives and compound nouns). Wordbuilding structures were also handled e.g. by Eve Clark and Ruth Berman. ${ }^{2}$ All studies concerned exclusively children in the intellectual norm.

In Poland, wordbuilding in linguistics was analysed by e.g. Maria Chmura-Klekotowa ${ }^{3}$ (she collected material made up of 5000 examples of wordbuilding neologisms), Maria Zarębina ${ }^{4}$ (described the creation of the child's language system and conducted an analysis of texts created by children at pre-school age and younger), Halina Zgółkowa ${ }^{5}$ (described the functions of neologisms in the development of language in preschool-age children), Ewa Muzyka-Furtak $^{6}$ (analysed and assessed the capacities to comprehens and create wordbuilding structures by deaf children), and in terms of psycholinguistics and psychology - e.g. by Ewa Haman and Amelia Dzi-

2 E.V Clark., R.A. Berman, Structure and use in the acquisition of word formation, "Language" 1984, no. 60, pp. 542-590; E.V Clark, R.A. Berman, Types of linguistic knowledge: interpreting and producing compound nouns, "Journal of Child Language" 1987, no. 3(14), pp. 547-567.

${ }^{3}$ M. Chumura, Uwagi o rozwoju mowy dziecka, „Poradnik Językowy” 1962, no. 9-10, pp. 449-456; M. Chmura-Klekotowa, Neologizmy stowotwórcze w mowie dzieci, „Poradnik Językowy" 1968, no. 1, pp. 19-25; M. Chmura, U. Napiórkowska, J. Nowak, $Z$ badań nad słownictwem dziecka rozpoczynającego naukę szkolna, "Życie Szkoły" 1970, no. 7-8, pp. 21-26; M. Chmura-Klekotowa, O różnicach w zasobie słownikowym dziecka siedmioletniego i dwunastoletniego, „Prace Filologiczne” 1975, no. 25, pp. 239-242.

${ }^{4}$ M. Zarębina, Kształtowanie się systemu językowego dziecka, Wyd. Ossolineum, Wrocław 1965; M. Zarębina, Rola wyrazów w słowniku i w tekście (na materiale polskim), „Język Polski” 1970, p. 43; M. Zarębina, Język polski w rozwoju jednostki. Analiza tekstów dzieci do wieku szkolnego. Rozwój semantyczny języka dziecka, Wydawnictwo Naukowe WSP, Kraków 1980.

${ }^{5}$ H. Zgółkowa, Funkcje neologizmów w rozwoju języka dzieci przedszkolnych, [in:] Jezzyk osobniczy jako przedmiot badań lingwistycznych, ed. by J. Brzeziński, Wydawnictwo Wyższej Szkoły Pedagogicznej w Zielonej Górze, Zielona Góra 1988, pp. 259-276.

${ }^{6}$ E. Muzyka-Furtak, Konstrukcje stowotwórcze w świadomości językowej dzieci niestyszacych, Wydawnictwo Uniwersytetu Marii Curie-Skłodowskiej, Lublin 2010.

${ }^{7}$ E. Haman, Stowotwórstwo dziecięce w badaniach psycholingwistycznych, "Język. Poznanie. Komunikacja" 2013, vol. 19, Warszawa. 
urda-Multan. ${ }^{8}$ All quoted studies were conducted exclusively among children in the intellectual norm.

Up to now, subject literature did not include broad linguistic studies dealing with wordbuilding structures in the consciousness of children with ID. ${ }^{9}$ Issues concerning wordbuilding in children with MID are at the stage of preliminary development. ${ }^{10}$

The conducted research on language of children with ID shows that they exhibit language disorders on every level of language ${ }^{11}$, hence, in the area of wordbuilding. The acquisition of wordbuilding rules and categories is closely tied to one's cognitive categories. Even though relations in the acquisition of cognitive and wordbuilding categories are noted, they were not analysed in detail until now - attempts were only made to discern between concept categories that are expressed in the Polish language by wordbuilding. ${ }^{12}$ Beside close ties between the acquisition of wordbuilding rules and cognitive functioning, mechanisms and techniques of derivation, which

${ }^{8}$ A. Dziurda-Multan, Dziecięce sposoby tworzenia nazw, Wydawnictwo KUL, Lublin 2008.

9 The researchers described language disorders in children with ID, however no study takes on issues concerning wordbuilding competences. Researchers working with the development of speech in children with ID include: A. Szuniewicz (1967), E. Minczakiewicz (1984, 1989, 1993a, 1993b, 1994), S. Sadowska (2006), L. Błeszyńska (2006), Z. Tarkowski (1988), H. Nadolska (1993, 1994), J. Bałachowicz and J. Paluszewski (1995), A. Rakowska (2003), U. Jęczeń (2005, 2007), M. Michalik (2006, 2011), K. Kaczorowska-Bray (2013, 2017), D. Krzemińska (2012), J. Błeszyński (2013, 2016), A. Wątorek (2014).

${ }_{10}$ R. Marciniak-Firadza, Kilka uwag o potrzebie badań kompetencji słowotwórczych dzieci z niepetnosprawnościa intelektualna w stopniu lekkim "Interdyscyplinarne Konteksty Pedagogiki Specjalnej” 2016, no. 14, pp. 29-51.

11 J. Błeszyński, K. Kaczorowska-Bray (ed.), Diagnoza i terapia logopedyczna osób $z$ niepetnosprawnościa intelektualna, Wydawnictwo Harmonia Universalis, Gdańsk 2012.

12 B. Szymanek, Categories and categorization in morphology, Wydawnictwo KUL, Lublin 1988; R. Grzegorczykowa, B. Szymanek, Kategorie stowotwórcze w perspektywie kognitywnejp, [in:] Wspótczesny język polski, ed. by J. Bartmiński, Wydawnictwo UMCS, Lublin 2001. 
serve the creation of new words, are significant for the purpose of analyses of specific properties of acquisition of wordbuilding categories. $^{13}$

\section{Speech development in children with MID}

Children with MID go through the same stages of speech development as children in the intellectual norm. In children with MID, however, it is characteristic for the individual stages to appear at a reduced pace and last longer than in their peers in the norm. ${ }^{14}$ The majority of preschool-age children is able to master the phonological, semantic and syntactic systems of a language, and thanks to the language resources at their disposal, they are able to initiate and maintain dialogue (make social contacts). ${ }^{15}$ Children understand statements by adults well.

The delayed development of speech in children with MID is expressed, among others, by the following:

- persistent incorrect articulation,

- slow pace of vocabulary acquisition,

13 A. Heinz, Fleksja a derywacja, "Język Polski” 1961, no. XLI(5), pp. 343-354.

14 A. Rakowska, Jezzyk - komunikacja - niepetnosprawność. Wybrane zagadnienia, Wydawnictwo Naukowe Akademii Pedagogicznej, Kraków 2003; E. Kulesza, Rozwój poznawczy dzieci z lekkim i umiarkowanym stopniem upośledzenia umysłowego - diagnoza i wspomaganie. Studia empiryczne, Wydawnictwo APS, Warszawa 2004; K. Kaczorowska-Bray, Zaburzenia komunikacji językowej w grupie osób z niepetnosprawnością intelektualną, [in:] Diagnoza i terapia logopedyczna osób z niepetnosprawnościa intelektualna, ed. by J. Błeszyński, K. Kaczorowska-Bray, Wydawnictwo Harmonia Universalis, Gdańsk 2012, pp. 36-64.

${ }^{15}$ H. Nartowska, Opóźnienia i dysharmonie rozwoju dziecka, Wydawnictwo WSiP, Warszawa 1980; A. Rakowska, Jezyk - komunikacja - niepetnosprawność. Wybrane zagadnienia, Wydawnictwo Naukowe Akademii Pedagogicznej, Kraków 2003; K. Kaczorowska-Bray, Zaburzenia komunikacji językowej w grupie osób z niepetnosprawnościa intelektualna, [in:] Diagnoza i terapia logopedyczna osób z niepetnosprawnościa intelektualna, ed. by J. Błeszyński, K. Kaczorowska-Bray, Wydawnictwo Harmonia Universalis, Gdańsk 2012, pp. 36-64. 
- reduced verbal activity,

- difficulty constructing correct sentence structures,

- persistent agrammatisms,

- difficulty speaking spontaneously on a given subject. ${ }^{16}$

The vocabulary of a child with MID is poor in abstract terms, as these people do not understand their meaning, hence, they do not take them up into their vocabulary resources.

\section{Methodology and subject of own research}

The present article constitutes a qualitative analysis of statements by a single child, and it is but an introduction to further extensive research on wordbuilding competences of pre-school children with MID.

\subsection{The characteristics of the analysed child}

The girl was born in 2012. On the day of the assessment, she was six years and 10 months old. On the basis of a psychological examination, using the WISC-R (Wechsler Intelligence Scale for Children), it was concluded that the intellectual functioning of the child hovers around mild intellectual disability. The medical statement concerning the need for special education concluded that the MID is most probably the result of the numerous illnesses that the child was diagnosed with. The supplied hospital medical information sheets of the girl indicate that her health significantly affects her cognitive and intellectual development. After an MRI examination of the head, the stabilisation of the optic nerve glioma and of the dysplastic changes within the scope of von Recklinghausen disease was found to have become stable. In addition, the child remains under the care of a neurological practice due to epilepsy, and of a vascular

16 A. Rakowska, Jezzyk - komunikacja - niepetnosprawność. Wybrane zagadnienia, Wydawnictwo Naukowe Akademii Pedagogicznej, Kraków 2003, p. 127. 
disease specialist due to the condition after deep vein thrombosis of the right extremity. The child attends an integration pre-school, also attended by children in the norm and with specific education needs ${ }^{17}$ (e.g. children with MID or with autism).

\subsection{Object of research}

The object of the analyses are suffix-based noun derivatives created on the basis of various parts of speech (e.g. nouns, verbs and adjectives), representing individual wordbuilding categories. Using classic and still valid linguistic works by Renata Grzegorczykowa and Jadwiga Puzynina18, the article analyses exclusively mutation derivatives in the following wordbuilding categories: names of activity actors, names of tools, places, products and objects of activities, names of entities bearing specific properties. Names of sets, inhabitants and family relations were omitted due to low productivity in colloquial speech.

\subsection{Research tool}

Due to the fact that there are no databases of questionnaires, surveys, tests or developed experimental models for testing of wordbuilding competences of children with MID, the study required the creation of a wordbuilding questionnaire on the basis of

17 The author purposefully uses the term specific needs in lieu of the term common in literature - special needs - thus argumenting in favour of Marzena Zaorska. The researcher states that the term special is not fitting, because the global needs of every person are the same, and this speciality applies solely to the scope, methods and forms of fulfilment of these needs. In addition, this term is less stigmatising (M. Zaorska, Aktualne problemy edukacji i rehabilitacji osób z niepetnosprawnością sprzężona, „Niepełnosprawność” 2012, no. 7, pp. 9-24).

18 R. Grzegorczykowa, J. Puzynina, Problemy ogólne stowotwórstwa. Rzeczownik, [in:] Gramatyka współczesnego języka polskiego. Morfologia, ed. by R. Grzegorczykowa, R. Laskowski, H. Wróbel, Wydawnictwo Naukowe PWN, Warszawa 1999, pp. 361-468. 
already developed references. ${ }^{19}$ It was composed of two parts - the first one, used to test comprehension, and the second one, used to test the production of wordbuilding structures. The skills in the comprehension of structures was tested using the technique concerning the formulation of a wordbuilding paraphrase, and the skill of production of structures using the technique entailing the recognition of derivatives - on the basis of the presented wordbuilding paraphrase.

\subsection{Test procedure}

The test was conducted in a quiet room, without the participation of third parties. Due to difficulties in longer-term attention focus in children with ID, and in order to eliminate the probability of a sudden drop in motivation due to fatigue, the test was subdivided into two meetings. According to the rules of skill acquisition in course of language acquisition, understanding structures precedes creation. The research work, however, was conducted in the reverse order. During the first diagnostic session, tested was the skill of production, and during the second - the ability to comprehend. The break between the assessments was at least two weeks, preventing the emergence of the child remembering the wordbuilding structures or modes of their creation discussed during the first meeting, and preventing them from repeating the same formants and analogous modes of production during the second session. The entire test lasted 40 minutes. The tasks from the questionnaire were read to the child, who would then respond. During the test, every effort was made for the child to have the best possible work conditions and to feel free; attempts were made to encourage her linguistic creativity, and she was encouraged to produce wordbuilding structures. The

${ }^{19}$ During development of the questionnaire, wordbuidling assessment methods were used as described and developed e.g. by E. Muzyka-Furtak (2010). The author worked with wordbuilding structures in the language consciousness of deaf children. 
study proper was preceded by a so-called "wordbuilding warm-up", which was meant to help the child comprehend the tasks from the questionnaire and invoke their wordbuilding creativity.

\section{Analysis of the material}

\subsection{Assessment of comprehension of wordbuilding structures belonging to the individual wordbuilding categories - the capacity to produce wordbuilding paraphrases}

Comprehension (decoding) is a formal-semantic analysis of structures; decoding the meanings of the constituent components of a formation; interpreting wordbuiling structures, according to social conventions and own experiences; the ability to produce a wordbuilding paraphrase indicating semantic reactions between the basic word and the derivative, thanks to the indication of the constituent components of a formation. ${ }^{20}$

The wordbuilding paraphrase is an analytical statement equivalent to the derivative, which contains the root word. ${ }^{21}$ The ability to create a wordbuilding paraphrase is identical to the ability to form sentences. Children with MID, due to dysfunctions of the syntactic efficiency of language, have trouble building correct sentences. This translates directly into the skil of creation of wordbuilding paraphrases. This dies not mean, however, that persons with MID are not able to build paraphrases at all. They make efforts to define derivatives and discern their meaning. A confirmation of this thesis are examples collected during this assessment, which were analysed.

${ }^{20}$ B. Kreja, Stowotwórstwo a problem tworzenia nowych wyrazów, [in:] Z zagadnień ogólnych polskiego słowotwórstwa. Studia 3, ed. by B. Kreja, Wydawnictwo Uniwersytetu Gdańskiego, Gdańsk 2000, p. 192.

${ }^{21}$ R. Grzegorczykowa, J. Puzynina, Problemy ogólne słowotwórstwa. Rzeczownik, [in:] Gramatyka współczesnego języka polskiego. Morfologia, ed. by R. Grzegorczykowa, R. Laskowski, H. Wróbel, Wydawnictwo Naukowe PWN, Warszawa 1999, p. 371. 
During the formulation of the paraphrase, the patient used explications of the structural meaning (without components of the real, actual meaning), for instance:

\section{Polish-language original}

Jadalnia - tam sie je

Samotnik - to jest taki bardzo, bardzo, Loner - he is so very, very, very lonely bardzo samotny

Brzuchacz - to jest taki, co ma brzucha

Wąsacz - kto ma wasy (a ja widziatam prawdziwego Mikotaja!)
Approximate English translation

Eating room - where you eat

Big-belly - someone with a belly

Moustache-face - one with a moustache

(and I saw the real Santa Claus!)

The material used one example of use of explication of the structural meaning with components of the real meaning, for instance:

Pralnia - to miejsce, gdzie nosi sie ubrania, Laundry room - it is a place where you no i zamyka się, no i pierze sie wear clothes, and where you close, and where you do laundry

Most commonly, however, during decoding, the patient indicated the root word with a component of the real meaning, for instance:

Sprzedawca - sprzedaje nam jakies tam Seller - somebody who sells us things like mleko, ogórki, pomidory, sałatę, chrupki milk, cucumbers, tomatoes, salad, corn puffs

Sprzątaczka - która sprzata; może sprzątać Cleaning lady - who cleans; she can clean podłoge, okna, kurze, szybe żeby była czysta (moja mama myje wszystko, nawet szafy)

Nauczyciel - uczy ptywać dzieci, skakać, Teacher - teaches children to swim, to jump, skakać wysoko the floor, the windows, the dust, the window, so that it is clean (my mum washes everything, even wardrobes)

Śpiewak - śpiewa wlazt kotek, ogórek Singer - sings row row, bus wheels (the kiszony (ogórek, ogórek zielony ma garniturek...), może śpiewać pieski małe dwa, jagódki

Słuchacz - że styszy burze, wiatr, deszcz, Listener - that they listen to the storm, btyskawice

Skakanka - do skakania wind, rain, lightning

Drukarka - do drukowania, wychodza karty, Printer - for printing, sheets, writing comes napisy

Pisak - to pisze się literki out

Pen - you can write letters 
Suszarka - do suszenia włosów; myjesz, Dryer - for drying hair; you wash, comb, czesze $i$ susze

Gaśnica - gasi ogień strażak and dry

Fire extinguisher - the fireman extinguishes the fire

Kwiaciarnia - kwiaty można wziać do do- Flower shop - You can take the flowers mu, zaptacić home, and pay

Wycieraczka - do okien i szyb wycierania Wash-cloth - for washing windows and [dziewczynka pokazywała] glass [the girl showed how]

A different mode of interpreting wordbuilding formations in a child was also the identification of the root word, and, accordingly - linking the meaning of the derivative with the meaning of the root word (created with its use). In this case, the meaning of the root word is more important for the meaning of the given word than the meaning of the formant, e. g:

Leżak - leży się

Czytanka - czyta sie
Beach chair - you lie

Reading-book - you read

In one of the examples, the giel used the verb root with a common root morpheme, however, with a different prefix, e.g.:

Grzejnik - do ogrzania domu

Heater - to heat the house

At times, the child would indicate the lexical meaning of the derivatives. Focusing exclusively on reading the real meaning, in the definition she omitted the root word, e.g.:

Lekarz - bada serce, nogi, plecy, uszy, Doctor - he examines the heart, the legs, brzuch; wbija zastrzyki, a ja tak bardzo nie back, ears, stomach; he makes injections, lubię zastrzyków, no bo boli

Piłkarz - to jak gole strzela Odkurzacz - do sprzątania podtogi and I don't like injections a lot, because they're painful

Footballer - how he scores

Vacuum cleaner - for cleaning the floor

One of the modes of interpretation of derivatives were also associations. They most commonly stemmed from the fact that the child associated wordbuilding structures with situations she experienced in life - when recognising the meaning of derivative words, she based her work on her own experiences, for instance: 
Przymierzalnia - ubrania kupować

Mrożonka - to jest zimno, zimno tam jest

Grubas - on jest zabawny

Lodowisko - można tam śmieci wyrzucać
Fitting-room - buying clothes

Frozen food - it's cold, it's cold there

Fatty - he's funny

Skating rink - you can throw away trash there

The last example is an expression of relationship with the word śmieciowisko [landfull] - hence the interpretation of the derivate.

\subsection{Assessment of the skill of production of wordbuilding structures in the individual wordbuilding categories - the skill to produce structures on the basis of a wordbuilding paraphrase}

Production is formal-semantic synthesis of properties making up the structure's meaning; encoding meanings into the wordbuilding structure; production referring specific entities from one's own vocabulary that are formally and semantically tied to the defined set of semantic properties; this takes place on the basis of a wordbuilding paraphrase and a set of semantic properties that were extracted from the structural meaning of the formation. ${ }^{22}$

Throughout the majority of the test, the patient created wordbuilding structures belonging to various wordbuidling categories correctly, for instance:

Pan, który maluje - malarz

Pan, który pracuje w kuchni - kucharz

Urządzenie, które służy do kierowania pojazdów - kierownica

Urządzenie, które służy do prania - pralka

Pokój, gdzie się sypia - sypialnia

Miejsce, gdzie ludzie piją kawę - kawiarnia
One who paints - painter

One who works in the kitchen - cook

Device used to control cars - steering wheel

Device used for cleaning laundry washing machine

The room where one sleeps - bedroom

Place, where people drink coffee - cafe

${ }^{22}$ J. Puzynina, Procesy nadawania i rozumienia komunikatów językowych a stowotwórstwo, „Prace Filologiczne” 1970, vol. XX, pp. 59-64; E. Muzyka-Furtak, Konstrukcje słowotwórcze w świadomości językowej dzieci niestyszacych, Wydawnictwo Uniwersytetu Marii Curie-Skłodowskiej, Lublin 2010, p. 81. 
Urządzenie poruszane przez wiatr - Device moved by wind - windmill wiatrak

Urządzenie do zapalania ognia - zapatki Device to light a fire - matches

Osoba, która jest bardzo chuda - chudzi- A person who is very thin - a skinny elec

Człowiek, który jest goły - golas person

A person without clothes - naked

The collected material also includes structures used through application of wrong formants - this stems from insufficient acquisition of the rules of formant repartition, despite the fact of mastering basic skills of creation of word formations, for instance:

Pan, który skacze - skakacz

Pan, który biega - biegarz

Pan, który mówi - mówiarz

Pan, który kłamie - kłamarz

Urządzenie, które służy do zmywania naczyń - zmywacz

Część ulicy przeznaczona do chodze- Part of the street used for walking / the nia/Powierzchnia, po której się chodzi - chodzik

Człowiek, który lubi zbierać grzyby - Person who likes to pick mushrooms grzybaw
One who jumps - jumpist

One who runs - runnist

One who speaks - speakist

One who lies - lyinger

Device used for cleaning dishes - dishcleaner mushroomer

translator's note: the translations offered above are but attempts at conveying the types of errors made by the patient as transposed to the English language. They are only approximations that should give an image of the issue.

For a child with MID, the addition of random formants characteristic for the category of actors, to intuitively derived root words, does not constitute any changes in meaning - this shows how rules of grammar are abstract for a child with ID, if they do not understand them.

Noteworthy are also structures created with a change of the root words, however, semantically and not formally related, with the root word used in the explication. The patient recalled, on the basis of association, words related to the components of the paraphrase that she understood, e.g.: 
Rzecz, która budzi ludzi rano - kogut Thing to wake us in the morning - rooster

Urządzenie, które służy do kopania - Device used for digging - shovel topata

Przyrząd, który służy do otwierania bu- Item used for opening bottles - cork telek - korek

Miejsce, gdzie ludzie pieką chleb i bułki Place, where people bake bread and buns - kuchenka - oven

Książeczka, w której koloruje się obrazki Book, in which you colour pictures - zeszyt, kartka

Pan, który ma brodę - Mikołaj notebook, paper sheet

Man with a beard - Santa Claus

At times, the patient did not create derivatives on the basis of the paraphrase she heard, but would only repeat the last word ${ }^{23}$, for instance:

Miejsce, gdzie ludzie kupują i jedzą lody Where people buy ice-cream - ice-cream - lody

Człowiek, który jest biedny - biedny

Pan, który jest stary - stary

Person who is poor - poor

Man who is old - old

One repetition emerged in an altered, declined form, meaning:

Rzecz do jedzenia zrobiona z cukru - Edible thing made of sugar - sugar cukier

Within all of the collected material, one structure was created using the wrong root word, and one from the wrong root word with the incorrect formant, e.g.:

Miejsce, gdzie są przyrządy do ćwiczeń Place with strength exercise equipment na siłę - ćwiczelnia

Pan, który łowi ryby - łowiarz exercisory

Man who fishes - fishman

[see earlier translator's note]

One of the examples saw the girl unable to decide the root word in the presented structure, as a result the last sound was removed;

${ }^{23}$ It is impossible to clearly state whether the child repeated the word being at the same time the root consciously or accidentally. 
it was probably accidental and not correct in terms of morphological boundaries, e.g.:

Miejsce, w którym można poczekać na Place, where you can wait for a train pociąg - poczekalni $(-a \rightarrow \varnothing)$ loung $(-e)$

The girl also used the word formation szmatka do ścierania 'rzecz, którą ścieramy podłogi' [wash-cloth 'thing for washing floors'].

\section{Summary}

A child experiencing ID-based language dysfunctions has hindered access to wordbuilding resources. In the presented case, comprehension exceeds production, a phenomenon typical for children in the intellectual norm as well. The child has difficulty forming sentences, which translates into difficulty formulating wordbuilding paraphrases. In the majority of cases, the girl indicated the root word with a component of the actual meaning - however, the parapohrase was only made up of components necessary for the identification of the meaning of the derivate. Disturbed abstract thinking and specific/image-based thinking contribute to the fact that when the girl formed paraphrases, she referred to specific designators, frequently listing them (e.g. the seller sells us things like milk, cucumbers, tomatoes, salad, corn puffs; the cleaning-lady can clean the floor, the windows, the dust, the window, so that it is clean). Maintaining at the stage of specific and specific-functional operations also influences frequent prevalence of associations that are based on the child's life experiences.

The child managed to produce correct structures on the basis of recalled wordbuilding paraphrases. One can surmise, however, that these were names the child could have come across earlier in life. The low level of acquisition of the rules of formant repartition, despite mastery in the basic skills of creation of formations, shone through in the creation of structures with wrong formants, frequently added at random and intuitively. Structures were also seen made 
using a different root word, which continued to be semantically related to the root word used for the explication. If the patient was unable to produce the correct formation, she repeated a part of the presented wordbuilding paraphrase.

Even though the child was able to express specific semantic and pragmatic intentions, she did not sufficiently acquire syntactic efficiency. Due to the failure to master, in the appropriate time, the rules of grammar, the patient, with quite an extensive vocabulary if one would consider the described dysfunction, continues to have problems producing word combinations and sentences. It may thus be surmised that all dysfunctions named above also translate to a reduced level of wordbuilding competences spanning comprehension and creation of wordbuilding structures.

Conclusions were drawn on the basis of a single assessment, hence they require confirmation with a higher number of cases - the conducted studies shall be executed in more detail and subjected to a much more thorough linguistic analysis. A broader perspective of the single case described here can allow the description of differences between comprehension and production skills concerning wordbuilding structures by children with MID and describe their level of wordbuilding competences. In addition, any detailed view of the research focused on the modes of production and understanding of noun derivatives in the area of the selected wordbuilding categories, and a comparison of the results with scores by children in the intellectual norm (on the basis of own research and with reference to the developed knowledge and the research history), would allow the determination of whether children with MID master mechanisms and techniques of derivation in the same way as children in the norm, and what is their level of wordbuilding competences. The collected material will also allow a comparison of wordbuilding competences of children with MID with wordbuilding skills of children with other disabilities/ dysfunctions.

To conclude, it must be noted that an assessment of the level of wordbuilding commpetences should be a component of a comprehensive logopaedic diagnosis (it is, however, frequently omitted in 
diagnosis). It is he more important that with children with language dysfunctions (including oligophasia), the observation of acquisition of wordbuilding rules allows more precise determination of speech therapy, the purpose being e.g. the reduction of interference in communication and the development of a suitable level of language competences and capacities.

\section{Bibliography}

[1] Bałachowicz J., Paluszewski J. (ed.), Sprawności językowe dzieci upośledzonych umystowo w stopniu lekkim, Wydawnictwo WSPS, Warszawa 1995.

[2] Berko J., The child's learning of English morphology, “Word" 1958, no. 14, pp. 150-177.

[3] Błeszyńska L., Zasób stownictwa uczniów z niepetnosprawnościa intelektualna w stopniu lekkim klas gimnazjalnych - diagnoza i propozycje rozwiazań, [in:] Nauczanie uczniów z niepetnosprawnościa intelektualna w stopniu lekkim. Wybrane problemy $z$ teorii i praktyki, ed. by S. Sadowska, Wydawnictwo Edukacyjne Akapit, Torun 2006, pp. 153-162.

[4] Błeszyński J., Kaczorowska-Bray K. (ed.), Diagnoza i terapia logopedyczna osób $z$ niepetnosprawnościa intelektualna, Wydawnictwo Harmonia Uniwervalis, Gdańsk 2012.

[5] Błeszyński J., Niepetnosprawność intelektualna. Mowa - język - komunikacja. Czy iloraz inteligencji wyjaśnia wszystko?, Harmonia, Gdańsk 2013.

[6] Chmura M., Napiórkowska U., Nowak J., Z badań nad stownictwem dziecka rozpoczynajacego naukę szkolna, „Życie Szkoły” 1970, no. 7-8, pp. 21-26.

[7] Chmura-Klekotowa M., Neologizmy stowotwórcze w mowie dzieci, „Poradnik Językowy" 1968, no. 1, pp. 19-25.

[8] Chmura-Klekotowa M., O różnicach w zasobie stownikowym dziecka siedmioletniego i dwunastoletniego, „Prace Filologiczne” 1975, no. 25, pp. 239-242.

[9] Chumura M., Uwagi o rozwoju mowy dziecka, „Poradnik Językowy” 1962, no. 9-10, pp. 449-456.

[10] Clark E.V, Berman R.A., Structure and use in the acquisition of word formation, “Language" 1984, no. 60, pp. 542-590.

[11] Clark E.V, Berman R.A., Types of linguistic knowledge: interpreting and producing compound nouns, "Journal of Child Language" 1987, no. 3(14), pp. 547-567.

[12] Dziurda-Multan A., Dziecięce sposoby tworzenia nazw, Wydawnictwo KUL, Lublin 2008.

[13] Grabias S., O ekspresywności języka. Ekspresja a stowotwórstwo, Wydawnictwo UMCS, Lublin 1980. 
[14] Grzegorczykowa R., Puzynina J., Problemy ogólne stowotwórstwa. Rzeczownik, [in:] Gramatyka wspótczesnego języka polskiego. Morfologia, ed. by R. Grzegorczykowa, R. Laskowski, H. Wróbel, Wydawnictwo Naukowe PWN, Warszawa 1999, pp. 361-468.

[15] Grzegorczykowa R., Szymanek B., Kategorie stowotwórcze w perspektywie kognitywnej, [in:] Wspótczesny język polski, ed. by J. Bartmiński, Wydawnictwo UMCS, Lublin 2001.

[16] Haman E., Stowotwórstwo dziecięce w badaniach psycholingwistycznych, „Język. Poznanie. Komunikacja" 2013, vol. 19, Warszawa.

[17] Heinz A., Fleksja a derywacja, „Język Polski” 1961, no. XLI (5), pp. 343-354.

[18] Jęczeń U., Językowa projekcja emocji na przykładzie wypowiedzi dzieci upośledzonych umystowo i dzieci w normie intelektualnej (unpublished dissertation), Lublin 2005.

[19] Jęczeń U., Jezzkowa projekcja emocji. Emocje w zachowaniach językowych dzieci upośledzonych umystowo i dzieci w normie intelektualnej, [in:] Jezzyk - interakcja - zaburzenia mowy. Metodologia badań, ed. by T. Woźniak, A. Domagała, Wydawnictwo UMCS, Lublin 2007, pp. 133-171.

[20] Kaczorowska-Bray K., Kompetencja i sprawność językowa dzieci z niepetnosprawnościa intelektualna w stopniu znacznym, umiarkowanym i lekkim, Wydawnictwo Uniwersytetu Gdańskiego, Gdańsk 2017.

[21] Kaczorowska-Bray K., Wyrażenia przyimkowe w mowie dzieci upośledzonych umystowo w stopniu umiarkowanym i lekkim, Wydawnictwo Harmonia Universalis, Gdańsk 2013.

[22] Kaczorowska-Bray K., Zaburzenia komunikacji językowej w grupie osób z niepetnosprawnością intelektualna, [in:] Diagnoza i terapia logopedyczna osób z niepetnosprawnościq intelektualna, ed. by J. Błeszyński, K. Kaczorowska-Bray, Wydawnictwo Harmonia Universalis, Gdańsk 2012, pp. 36-64.

[23] Kreja B., Stowotwórstwo a problem tworzenia nowych wyrazów, [in:] Z zagadnień ogólnych polskiego stowotwórstwa. Studia 3, ed. by B. Kreja, Wydawnictwo Uniwersytetu Gdańskiego, Gdańsk 2000, pp. 191-195.

[24] Krzemińska D., Jezyk i dyskurs codzienny osób z niepetnosprawnościa intelektualna, Oficyna Wydawnicza „Impuls”, Kraków 2012.

[25] Kulesza E., Rozwój poznawczy dzieci z lekkim i umiarkowanym stopniem upośledzenia umystowego - diagnoza i wspomaganie. Studia empiryczne, Wydawnictwo APS, Warszawa 2004.

[26] Marciniak-Firadza R., Kilka uwag o potrzebie badań kompetencji stowotwórczych dzieci z niepetnosprawnościa intelektualna w stopniu lekkim „Interdyscyplinarne Konteksty Pedagogiki Specjalnej” 2016, no. 14, pp. 29-51.

[27] Marciniak-Firadza R., Kilka uwag o stanie badań nad kompetencją stowotwórcza dzieci z niepetnosprawnościa intelektualna, „Interdyscyplinarne Konteksty Pedagogiki Specjalnej" 2017, no. 18, pp. 145-163. 
[28] Michalik M., Diagnozowanie kompetencji lingwistycznej ucznia szkoły specjalnej, Wydawnictwo Naukowe Akademii Pedagogicznej, Kraków 2006.

[29] Michalik M., Kompetencja sktadniowa $w$ normie $i$ w zaburzeniach, Wydawnictwo Naukowe Uniwersytetu Pedagogicznego, Kraków 2011.

[30] Minczakiewicz E., Kształtowanie i usprawnianie mowy dzieci upośledzonych umystowo w stopniu umiarkowanym i znacznym, „Szkoła Specjalna” 1984, no. 3, pp. 186-191.

[31] Minczakiewicz E., Rozwój języka mówionego uczniów młodszych klas szkoty specjalnej dla lekko upośledzonych umystowo w toku zamierzonych oddziatywań stymulacyjnych, „Logopedia” 1994, no. 21, pp. 37-46.

[32] Minczakiewicz E., Z badań nad zaburzeniami mowy u dzieci upośledzonych umystowo, [in:] Z zagadnień oligofrenopedagogiki, ed. by J. Pańczyk, vol. 2, Wydawnictwo WSPS, Warszawa 1989.

[33] Minczakiewicz E., Zaburzenia mowy $i$ ich odbicie w piśmie uczniów młodszych klas szkoły specjalnej dla lekko upośledzonych umystowo, „Logopedia” 1993, no. 20, pp. 113-119.

[34] Minczakiewicz E., Zaburzenia mowy u osób z upośledzeniem umystowym, „Scholasticus" 1993, no. 1, pp. 57-63.

[35] Muzyka-Furtak E., Konstrukcje stowotwórcze w świadomości jezzykowej dzieci niestyszacych, Wydawnictwo Uniwersytetu Marii Curie-Skłodowskiej, Lublin 2010.

[36] Nadolska H., Kompetencja narracyjna uczniów o różnym poziomie intelektualnym. Przejawy, uwarunkowania, tendencje rozwojowe, Wydawnictwo Erbe, Białystok 1995.

[37] Nadolska H., Poziom inteligencji a sprawność narracji, „Roczniki Pedagogiki Specjalnej" 1994, no. 5, pp. 43-61.

[38] Nadolska H., Poziom inteligencji a sprawność relacjonowania zdarzeń. Wybrane aspekty badań nad kompetencja narracyjna dzieci petnosprawnych i upośledzonych umystowo w stopniu lekkim, „Kultura i Edukacja” 1993, no. 4, pp. 91-102.

[39] Nartowska H., Opóźnienia i dysharmonie rozwoju dziecka, Wydawnictwo WSiP, Warszawa 1980.

[40] Puzynina J., Procesy nadawania i rozumienia komunikatów językowych a stowotwórstwo, „Prace Filologiczne” 1970, vol. XX, pp. 59-64.

[41] Rakowska A., Język - komunikacja - niepetnosprawność. Wybrane zagadnienia, Wydawnictwo Naukowe Akademii Pedagogicznej, Kraków 2003.

[42] Sadowska S., Uczeń z niepetnosprawnością intelektualną w stopniu lekkim w szkolnej sytuacji komunikacyjnej. O realizacji zadań wspomagania rozwoju umiejętności mówienia i pisania, [in:] Nauczanie uczniów z niepetnosprawnościa intelektualna w stopniu lekkim. Wybrane problemy z teorii i praktyki, ed. by S. Sadowska, Wydawnictwo Edukacyjne Akapit, Toruń 2006, pp. 127-151.

[43] Szuniewicz A., Próba badania wad mowy dzieci upośledzonych umysłowo w warszawskich szkołach specjalnych, „Logopedia” 1967, no. 7, pp. 112-117. 
[44] Szymanek B., Categories and categorization in morphology, Wydawnictwo KUL, Lublin 1988.

[45] Tarkowski Z., Agramatyzm u uczniów lekko upośledzonych umystowo, [in:] Rewalidacja dzieci ze złożonymi upośledzeniami, ed. by Z. Sękowska, Wydawnictwo UMCS, Lublin 1988, pp. 81-108.

[46] Wątorek A., Kompetencja językowa uczniów z lekka niepetnosprawnościa intelektualnq, Wydawnictwo Nomos, Kraków 2014.

[47] Zaorska M., Aktualne problemy edukacji i rehabilitacji osób z niepetnosprawnością sprzężona, "Niepełnosprawność” 2012, no. 7, pp. 9-24.

[48] Zarębina M., Jezzyk polski w rozwoju jednostki. Analiza tekstów dzieci do wieku szkolnego. Rozwój semantyczny języka dziecka, Wydawnictwo Naukowe WSP, Kraków 1980.

[49] Zarębina M., Ksztattowanie się systemu językowego dziecka, Wydawnictwo Ossolineum, Wrocław 1965.

[50] Zarębina M., Rola wyrazów w stowniku i w tekście (na materiale polskim), "Język Polski" 1970, p. 43.

[51] Zgółkowa H., Funkcje neologizmów w rozwoju języka dzieci przedszkolnych, [in:] Jezzyk osobniczy jako przedmiot badań lingwistycznych, ed. by J. Brzeziński, Wydawnictwo Wyższej Szkoły Pedagogicznej w Zielonej Górze, Zielona Góra 1988, pp. 259-276. 